\title{
An Ontological Vindication of Darl's Existential Authenticity from a Heideggerian Point of View
}

\author{
Fazel Asadi Amjad \\ Faculty of Humanities, Department of English Language and Literature \\ Kharazmi University of Tehran, Iran \\ E-mail: asadi@mail.khu.ac.ir \\ Reza Kazemifar (Corresponding author) \\ Faculty of Humanities, Department of English Language and Literature \\ Kharazmi University of Tehran, Iran \\ Tel: (+98)919-092-7651 E-mail: kazemifar@yandex.com
}

Received: 23-08-2013

doi:10.7575/aiac.ijalel.v.3n.1p.63
Accepted: 07-10-2013

Published: 01-01-2014

\begin{abstract}
Many existential theorists have discussed the contrasts between the notions of authentic and inauthentic lives, among whom Martin Heidegger (1889-1976) is very influential. The present paper aims at proving William Faulkner's (18971962) main character, Darl, in his novel, As I Lay Dying (1930), authentic from a Heideggerian point of view. Once the theoretical grounds are laid in detail, the analysis begins with focusing on the individual character, goes on by ontologically individualizing him, and finally proves his existential nonconformity with emphasis on the affective side of his Being rather than its rational side. After unveiling his nonconformity, it will be revealed that this nonconformity is unique to him, and this fact is among the factors making him authentic from a Heideggerian point of view; for what Heidegger calls authentic existence is achieved only when a means is discovered to rescue the individual from doing "as One does" to doing as he chooses to do himself. Freedom and responsibility, which are expanded upon, are the means by which Darl proves himself authentic.
\end{abstract}

Keywords: Martin Heidegger, existentialism, phenomenology, William Faulkner, As I Lay Dying, Darl

\section{Introduction}

Pre-Heideggerian ontology was concerned with the kinds of entities existing. The big metaphysical questions were the ones like "does God exist?" or "does such a thing actually exist?" (Gelven, 1989, p. 6). These questions were usually answered by making things fall into classes or genera, or what Aristotle called categories (Inwood, 1997, p. 16). But this required, as Martin Heidegger (1889-1976) believed, to know what existence means before putting the entities under such labels. Of course a great philosopher like Aristotle, for example, distinguishes between prote ousia and the rest of the beings predicating it through his ousiology (Sheehan, 2005, p. 193); but Heidegger's question regarding the meaning of Being is much more fundamental: "what does it mean to be?" He wants to know what it means to exist at all. Heidegger's basic diagnostic about the errors of his predecessors is that "their failure to pose the question of Being correctly is caused by and is itself a failure of authenticity" (Mulhall, 2005, p. 33). He makes ontology precede epistemology and is suspicious of the three elements involved in epistemology, i. e. knower, known, and their relation, knowing (Inwood, 1997, p. 13). Epistemology asks about the entities while ontology inquires into the meaning of Being. By Being Heidegger does not mean beings or entities, but that Being Aristotle considered ambiguous and many others considered universal, self-evident, or undefinable ${ }^{\mathrm{ii}}$.

Pre-Heideggerian philosophers always liked homogenizing the being of entities. To name one among many, Descartes recognizes the difference between res cogitans, the thinking thing, and res extensa, the other extended things. Heidegger proposes that such a mistake is due to the fact that they always focus on individual entities (beings) and ignore the context in which they lie. The remedy to this kind of misconception was Heidegger's concept of vorhanden which elaborates on one of the ways we see the world and makes the relationships crystal-clear (Inwood, 1997, p. 19).

Heidegger considers the Being-question ${ }^{\text {iii }}$, Seinsfrage, the most fundamental question in philosophy. It is the most important thing to know the meaning of Being, or what it means to be. Heidegger emphasizes that meaning precedes entity, "for the meaning ultimately explains the entity" (Gelven, 1989, p. 8). Seinsfrage "is concerned with what it is that makes beings intelligible as beings", i. e. what it means to be. Therefore Heidegger has opened a new way in philosophy which he himself calls fundamental ontology. Fundamental ontology is "the study of the 'meaning of Being' (der Sinn von Sein) as the foundation of the entire edifice of philosophy" (ibid). The Stanford Encyclopedia of Philosophy distinguishes between "regional ontology", which is the ontology of a certain domain, e. g. biology, and "fundamental ontology" (Wheeler, 2013). 
How can the Seinsfrage be approached? According to Gelven (1989), Heidegger believes that "only man can reflect upon what it means to be" and "Being can be realized or analyzed only through the self-reflective consciousness of human existence"; Gelven continues, "the only way in which Heidegger's analysis of human existence can provide a foundation for the question of Being is that the term 'Being' be read within the context of his thought" (p. 19). We see it is meaningless to separate the study of man from the study of the Seinsfrage, according to Heidegger. We have a vague awareness of our own existence, but this vague awareness should be made explicit. He uses the term Dasein (Da (here/there) and Sein (to be)) for a being which can inquire into its own Being. For Dasein's way of Being is existence, "a human being always embodies an understanding of its being", Dreyfus (1995) confirms and goes on to say that this understanding of Being is exclusively Dasein's idiosyncrasy (p. 16). Heidegger uses the word to refer to both the Being of humans and the entity of humans who have this Being (Inwood, 1999, p. 42). Heidegger uses the word existenz to indicate the kind of existence which is only applicable to Dasein, and the word existentia to indicate the existence of other entities (Heidegger, 2001, p. 67). Dasein's existenz refers to the fact that only Dasein can stand back from, observe, and be aware of its existence. The ways through which Dasein becomes aware of its existence are the existentials. The existentials are a priori (which are necessary and natural attitudes of mind) and will be discussed later. The a priori knowledge precedes experience and makes it possible. They are necessary and guarantee universal validity. Categories and existentials are both a priori, the former imposing order on things other than the mind, the latter the mind itself. Existentials are applicable to the modes of Being (not beings) through hermeneutic phenomenology (Gelven, 1989, p. 55).

Reviewing different kinds of philosophical investigation, ontic and ontological, is important in Heideggerian philosophy as well. In considering the differences between ontic and ontological investigations, the ontic factical roles oppose the ontological existentials and the ontic factual properties oppose the ontological categories. "Existential understanding is a worked-out understanding of the ontological structures of existence, that is, of what it is to be Dasein"; and "existentiell understanding is an individual's understanding of his or her own way to be, that is, of what he or she is" (Dreyfus H. L., 1995, p. 20). In describing Dasein, Heidegger asserts that "Dasein is ontically distinctive in that it is ontological" (16). Dasein is ontically, ontologically and fundamentally prior, because of its existence and its ability to be asked about such an existence and providing the foundation for all philosophy by the questioning of its existence, respectively (Heidegger, 2001, p. 34). It also should be taken into consideration that Dasein's essence lies in its existence. This means that the concept of Dasein rejects Sartre's view of man that man's existence precedes his essence. And as a final note, the mineness (eigen, own) of Dasein, this hermeneutic self-reflection, indicates the availability of the object of inquiry. Heidegger applies the term eigentlich, authentic, for "the mode of Dasein's existence in which one is aware of one's own existence," (Gelven, 1989, p. 50), while the term uneigentlich, inauthentic, is used to indicate the mode in which one is not aware of one's own existence. In this latter kind of existence, one sees one's self simply as others see it, which is other than one's existence. The distinction between authentic and inauthentic lays the ground for the analysis of the existentials (ibid).

\section{Theoretical Grounds}

\subsection{Existentialism}

"None of the great existentialist tomes contains the word "existentialism", Cooper (1999) writes in the first page of his book (p. 1). The word "existentialism" was coined by Gabriel Marcel (1889-1973), to refer to Sartre's philosophy; but Sartre, at first, rejected the label. Jean-Paul Sartre, Simon de Beauvoir (1908-86), Karl Jaspers (1883-1969), Albert Camus (1913-60), Maurice Merleau-Ponty (1908-61), Marcel himself, and Heidegger are among the famous existential philosophers. The roots of this philosophy are said to be in the works of the two enfants terribles of the nineteenth century, Soren Kierkegaard (1813-85) and Friedrich Nietzsche (1844-1900). Dreyfus (2006), in an article, traces the roots of the movement and makes a comparison between traditional philosophy and existential philosophy; "existential thinking defines itself in opposition to the philosophical tradition," and suggests that the best way to find out what existentialism is "is to lay out the essence of traditional philosophy from the point of view of the existentialists" (p. 139). Many others, among them novelists like Kafka and Dostoyevsky (1821-81), took the label quickly. Phenomenology and existentialism are two of the main philosophical movements of the twentieth century. "While phenomenology and existentialism are independent movements, they are compatible in principle and, indeed, that they have 'at least enough affinity for fruitful cooperation'”, Wrathall and Dreyfus (2006) quote Hubert Spiegelberg (p. 1). They continue that Heidegger considered his own work as "true to the genuine spirit of phenomenology," although he stopped referring to his work as "phenomenological". It was in order to distance himself from Husserlian phenomenology which is "a reflective, descriptive clarification of eidetic features" (Crowell, 2006, p. 11). Existentialism begins its analysis with the existing individual - being engaged in a world. The emphasis is more on the affective side of the human being than its rational side. What is unique to the individual should be unveiled. Human freedom and responsibility are focused upon. The goal of this freedom and responsibility is to live authentically. Existentialism is non-subjective, non-objective, anti-essentialist, anti-empiricist, and anti-rationalistic in their absolute senses of the words (Wrathall \& Dreyfus, 2006, p. 4).

\subsection{Heideggerian Hermeneutic (Existential) Phenomenology}

Being, in ontology for Heidegger, is just like space and time in empirical intuition for Kant. It is not thematic. The beings are thematic, but the Being is not. Hence, Heidegger believes, phenomenology is the way of access to, and the demonstrative manner of determination of, what is to become the theme of ontology and "only as phenomenology, is ontology possible" (Heidegger, 2001, p. 60) and "all philosophy must be phenomenology" (Inwood, 1999, p. 159). 
Dasein's understanding of Being also is not thematic. Phenomenology brings the structure of this non-thematic understanding under the light and makes it explicit while Dasein encounters beings. In contrast to Husserl's pure phenomenology, Heidegger proposes hermeneutic phenomenology which involves interpretation. The understanding of Dasein's of its Being (which occurs as existential facts) is to be made explicit ontologically. "Hermeneutik is now not interpretation, but the doctrine or study of interpretation" and Heidegger "uses Hermeneutik to mean 'interpretation', interpretation of 'facticity', that is of our own Dasein" (p. 87). Husserl's phenomenology was to achieve a vision of consciousness totally untainted by interpretations or systems, i. e. "to let the facts speak for themselves, as it were" (Gelven, 1989, p. 38), which reminds us of Husserl's famous motto, Zu den Sachen Selbst! But Heidegger's phenomenology is hermeneutic, i. e. interpretive (Heidegger, 2001, p. 62). Here, the contrast between the two philosophers shows up more prominently. Hermeneutic phenomenology only applies to "a case in which the facts were not in principle separate from the meanings of facts" (Gelven, 1989, p. 39). So this method is to be only applied to the question of existence, and in this kind of inquiry, the non-thematic meaning of an existential fact is made thematic. It must be shown how a particular existential fact (like fear) relates to the whole of Dasein's existence. It is shown what it means to be afraid, for example, by indicating how fear relates to the Seinsfrage. This procedure is circular, but not unacceptable. From a whole, vague, and unanalyzed experience we proceed to the part, i. e. a particular existential, and then to a new whole, i. e. the ontological understanding of existence.

\section{Discussion}

As I Lay Dying (1930) is among William Faulkner's (1897-1962) shortest works and tells "the story of the death and burial of Addie Bundren from multiple perspectives" (Fargnoli, Golay, \& Hamblin, 2008, p. 45). "Experimental in both subject and narrative structure", Head (2006) writes, the novel is "divided into 59 short interior monologues" (p. 45) and "as readers, we sift through the voices to find out whom to trust, which version of narrative to believe" (Towner, 2008, p. 24). Darl is Anse's and Addie's second son. He is "intelligent", "imaginative", "jealous", and "mentally unstable" (Fargnoli, Golay, \& Hamblin, 2008, p. 51). This mental instability is our clue to the existential authenticity of Darl. Many existential theorists have discussed the contrast between the notion of authentic and inauthentic life (Kaufman, 1975, p. 50). Heidegger makes it clear that "our daily being-in-the-world is inauthentic in that it is seldom in our control. What he calls authentic existence is achieved only when a means is discovered to rescue the individual from doing 'as One does' to doing as he chooses to do himself' (Calhoun, 1963, p. 5). In this case, Darl's mental instability is that "means" Heidegger is speaking about, and his final madness is the consequence of his freedom.

\subsection{Actuality and Possibility}

The authentic mode of existence, being aware of the meaning of existence, is concerned with possibility and the inauthentic mode with actuality. Dasein's actual conditions are determined and unchangeable.

"Why aint I a town boy, pa?" I said. (Faulkner, 1957, p. 86)

They are inevitable. Dasein is aware of its actuality; but at the same time Dasein is aware of its possibilities to be something else; so at the same time Dasein is free and has freedom. Both modes, actuality and possibility, are important to Dasein. Heidegger analyzes these modes phenomenologically and lets them reveal themselves in the fullness of their own significance. He believes that the two modes are equally primordial (Gelven, 1989, p. 78) and after this description, he brings and unifies the two terms under one existential, i. e. Sorge, care. The mode in which Dasein's actuality is revealed is called Befindlichkeit or "state-of-mind" (Heidegger, 2001, p. 172), and the mode in which Dasein's possibilities are revealed is called Verstehen or "understanding" (Heidegger, 2001, p. 183). They are both existentials, and equiprimordial, but Heidegger puts more significance on possibility than actuality (possibility is prior to actuality). Metaphysics puts actuality prior to possibility and considers it more real, for metaphysic's concern is with beings (Seiende) not Being (Sein). But Heidegger considers possibility more meaningful (he is to discover the meaning of Being). Although possibility is more important than actuality, to be authentic needs being aware of the actuality as well.

\subsubsection{Befindlichkeit}

It has roughly been translated to "state-of-mind". This existential helps Dasein find itself thrown in a world in certain situations and determined by conditions. Vardaman is a worthy example of one being aware of one's actuality and thrownness:

"Why aint I a town boy, pa?" I said. God made me. I did not said to God to made me in the country. If He can make the train, why can't He make them all in the town because flour and sugar and coffee. (Faulkner, 1957, p. 86)

The thrownness (Geworfenheit) is revealed through this existential. This disclosure (Erschlossenheit) matters to Dasein and is of importance to it (Heidegger, 2001, p. 176). Darl finds himself losing his mother and although it matters to him, he cannot help it:

"Jewel," I say, "do you know that Addie Bundren is going to die? Addie Bundren is going to die?" (Faulkner, 1957, p. 52)

And finally he finds his mother dead, and again the actuality of condition cannot be changed:

Jewel, I say, she is dead, Jewel. Addie Bundren is dead. (Faulkner, 1957, p. 70)

Or Jewel finds himself in a family in which the mother is pestered and tormented by the other members: 
It's because he stays out there, right under the window, hammering and sawing on that goddamn box. Where she's got to see him. Where every breath she draws is full of his knocking and sawing where she can see him saying See. See what a good one I am making for you. I told him to go somewhere else. (Faulkner, 1957, p. 22)

Therefore state-of-mind discloses Dasein's actual here (Da), which is a fact with an unknown part: why and for what ends is Dasein there in the world? By this existential Dasein has its moods; Dasein is always in a mood. Thus moods reveal facts with unknown parts to Dasein about its thrownness in the world. We are both fated and free; and we should tune ourselves into the world as a whole. We should fit into the world comfortably or not. This way of determined Being is called Stimmung or mood. Through moods we are attuned (Gestimmtsein) in the world (Heidegger, 2001, p. 172). They are not under our control and cannot be made to happen. Finally, finding ourselves in certain moods is called Befindlichkeit. Moods are a priori and their unintelligibility makes our existence intelligible. State-of-mind is the proof that the world matters to Dasein. There should be a mode of human existence prior to the occurrence of any fact that would make that occurrence significant as a fact, and hence facts can matter to Dasein. This mode should be prior to the fact, hence is an existential (again state-of-mind). Therefore moods reveal Dasein's concern for the facts as facts. Through moods Dasein relates to the givenness of its world.

Dasein, as is free, projects possibilities. This projection is equiprimordial to Befindlichkeit (Heidegger, 2001, p. 185). Authentic existence cannot exterminate the influence of its state-of-mind, but it can transcend it. State-of-mind belongs to Dasein and is one of its essential characteristics.

Darl is fearing his mother's death when he disbelievingly asks "do you know Addie Bundren is going to die?" (Faulkner, 1957, p. 52). Fear is one of the modes of state-of-mind (mood). It's discovered. It "has already disclosed the world, in that out of it something like the fearsome may come close" (Heidegger, 2001, p. 180). It means that there always is something in the world which can intimidate us and we are closely concerned with the world. Hence we are always open to this threat, or as Gelven says, it's "a way of Being in the world so that a part of it can threaten us. (...) Fear is not, then, reduced to a mere and occasional moment of weakness" (Gelven, 1989, p. 85). Fear is rather an important revelation of the truth that to be is, for Dasein, an issue. "For it is not possible to explain fear unless it matters for Dasein to be" (ibid). Fearing is feasible due to Dasein's possession, as an existential, of state-of-mind. Dasein's existence is determined by a concern for what is, and what is is a mode of its existence. Darl talks about his actuality after the death of his mother:

"Then what is your ma, Darl?" I said.

"I haven't got ere one," Darl said. "Because if I had one, it is was. And if it is was, it cant be is. Can it?"

"No," I said.

"Then I am not," Darl said. “Am I?"

"No," I said.

I am. Darl is my brother.

"But you are, Darl," I said.

"I know it," Darl said. "That's why I am not is. Are is too many for one woman to foal." (Faulkner, 1957, p. 127)

And finally through the very Befindlichkeit Darl becomes aware of his own ' $\mathrm{Da}$ ' and questions the awareness of his brother, Jewel:

I dont know what I am. I dont know if I am or not. Jewel knows he is, because he does not know that he does not know whether he is or not. (Faulkner, 1957, p. 105)

\subsubsection{Verstehen}

Verstehen, or understanding, is the existential which makes Dasein aware of its possibilities. This a priori existential reveals the manner in which Dasein exists. It is not restricted to cognition. It tells us both how we think and how we are; thinking is only one of the functions of Being. Understanding reveals to Dasein its existence-structure, and only through such revelation can Dasein use this existential in its purely cognitive function. Understanding makes Dasein able to be. Gelven writes, "my own existence is a possibility stretching out before me, about which I concern myself, and over which I have some control. I not only exist, but my ability to exist is a part of my mode of existing" (Gelven, 1989, p. 87). Understanding is rooted in Seinkonnen, i. e. Dasein's ability-to-be. The possibilities are not computed by the cognition and then to be applied to Dasein's situation; but they are owned by Dasein before being known to it. Of course to have possibilities requires being aware of them. Understanding is a kind of Entwurf, projection. Dasein's primordial relation to the world is ready-at-hand, or "available for use" as "equipment" (Malpas, 2003, p. 153). This is a relationship of for-the-sake-of. It means that Dasein uses the world for its own sake. The world also should present itself to Dasein in order to be used by it. Hence the world continually presents itself to Dasein's projections (possibilities). The world presents itself to us as "possible ways of service" (Gelven, 1989, p. 88). Heidegger insists that "the purely cognitive functions of understanding are generated from the existential awareness of possibilities, and that this awareness itself is based on being able to exist in various ways" (ibid). This means to philosophy a challenge to epistemology, because the latter considers cognition independent of freedom. Dasein projects possibilities. This projection itself is another existential; hence the projection of the possible ways of existence before Dasein by itself is 
another one of Dasein's characteristics. So we take Dasein into consideration not factually but factically, i. e. ontologically. Dasein is factically more than what it factually is; because it is more in terms of its possibilities than in terms of its actualities. Dasein is always looking ahead (Heidegger, 2001, p. 309). Thinking presupposes possibilities (possibilities are prior to thinking) and possibilities are also prior to experience. So from where do possibilities come? Indeed from the existence-structure of Dasein. Being able to think of possibilities requires Dasein to have the ability to do it. Epistemology cannot be purely worked out by cognition. Cognition is secondary to existential aspects of Dasein. Now, how does one relate to the two demesnes? Of course through existence. Heidegger believes, "pure reason is impossible without existential significance: I think of possibilities because I have possibilities and because I find myself to be a nest of possibilities" (Gelven, 1989, p. 91).

Dasein finds itself in the world in two ways, state-of-mind and understanding, which are equiprimordial. The former is concerned with "Da" and reveals to Dasein its facticity while the latter reveals to Dasein its existence (through possibilities). We also see possibilities have two kinds of meaning, existential and cognitive, the first of which being prior to the second. Heidegger begins with an account of how one's possible ways-to-be reveal themselves and how this manner of existing becomes manifest as meaningful assertions. So Dasein's existence precedes its knowing of it. What understanding projects (i. e. possibilities), interpretation works out. Interpretation "makes explicit what is already within the range of human awareness" (Gelven, 1989, p. 94). World as ready-at-hand ${ }^{\text {iv }}$ is interpreted. Interpretation has three constituents: the as-structure, the fore-structure, and the meaning. Up to here, it should be kept in mind that "Dasein, through understanding's projection of possibilities, makes explicit to us what is to be interpreted" (ibid).

Interpretation makes the as-structure explicit. As-structure indicates the usability (in-order-to) of a thing while being dealt with in a ready-at-hand mode. The use of a thing is already there in it and interpretation makes it explicit, to see the thing as that thing.

Meaning, on the other hand, is the "understanding" becoming aware of the "as-structure". It is understanding a thing as a thing. Word meaning is a derivative kind of meaning. Gelven indicates that Heidegger considers meaning a mode of Being in the world:

I can at times focus upon the ways in which I make use of the world. When such focusing occurs, the specific manner in which that part of the world becomes available to me is made explicit. When such explication occurs, I say that the way in which I make use of the world is meaningful. Meaning, then, is a mode of my Being here in a world (Gelven, 1989, p. 98).

One of the things Dasein uses in a ready-at-hand manner is the language. Accordingly, in a part of the novel, Addie says:

I learned that words are no good; that words don't ever fit even what they are trying to say at. When he was born I knew that motherhood was invented by someone who had to have a word for it because the ones that had the children didn’t care whether there was a word for it or not. (Faulkner, 1957, p. 221)

Addie agrees with Heidegger's opinion that meaning is prior to words, for we first have meaning and only then put them into words. Therefore verbal meaning is a derivative form of existential meaning. Addie's judgments have, in a derivative sense, meaning. They derive propositional meaning from existential meaning. Thus here is a shift from readiness-at-hand to presence-at-hand: Addie sees the words (or language) not as (hermeneutical as) is used, but as (apophantical $a s^{v}$ ) is known mere theoretically. We should beware that when the apophantical "as" occurs, i. e. the apophantical use of language analysis, the doors to fundamental ontology are closed.

\subsubsection{Rede}

The whole language (Sprache) is based on talk (Rede) (Heidegger, 2001, p. 203). The latter is the existential basis for the former. Talk is existentially significant. There's an existential situation in communication which is more important than the words. Vardaman cannot understand Darl's suggestion of Jewel's illegitimacy:

"Jewel's mother is a horse," Darl said.

"Then mine can be a fish, cant it, Darl?" I said.

Jewel is my brother.

"Then mine will have to be a horse, too," I said.

"Why?" Darl said. "If pa is your pa, why does your ma have to be a horse just because Jewel's is?" (Faulkner, 1957, p. 127)

Talk is "essentially a characteristic of Daseins interrelating to each other, intrigued by the commerce of things in the world and the many subtle relations with other humans" (Gelven, 1989, p. 104). Sentences are expressions of the existential manner through which Dasein relates to the world; they are derived, not primordial. This being derived is two steps backward: the existential ground is talk and the expression of talk is language. Language is used (ready-athand). When Daseins speak to each other, they do not hear the words, but the message. Language is used in order that our talk be made explicit. Daseins need their talks, what Vardaman lacks in our case, in order to use language for communication. 


\subsubsection{Verfallen}

Fallenness is not concerned with something sinful or reprehensible. It is the case when Dasein (as frequently does) loses its awareness of itself and is absorbed in the inauthenticity of the anonymous "they" (Heidegger, 2001, p. 220). Hence Dasein is fallen from its awareness of itself. That is unawareness of the Seinsfrage. Gelven writes:

(...) Heidegger has shown that the phenomenon of inauthenticity is not merely a vague and general feeling of alienation, but a very specific mode of human existence, which is open to inquiry. (...) [It is important that] such an analysis can be done (Gelven, 1989, p. 109).

In the following discussions the un-fallenness of Darl is approached to.

\subsubsection{Dread}

In everyone's life, there are moments of "uncanny"vi (Heidegger, 2001, p. 203) and surreal experience when one finds everything in the world alien and strange. The world loses its significance and one reflects on one's existence. Normal daily concerns do not matter to us and we find ourselves independent of our normal concerns. This state is called Angst by Heidegger and translated as anxiety by Macquarrie and Robinson (Heidegger, 2001, p. 227). Actually it is not an experience because it is not concerned with anything external. It only removes us from our daily and normal concerns and lets us think deeply about our terrifying existence. Heidegger's practice is done phenomenologically, existentially, and ontologically, respectively. Heidegger distinguishes between dread and fear. Fear does have an external object that is feared. But what's the external object and cause of dread? Nothing, or what Heidegger calls Nichts, Nothingness (Heidegger, 2001, p. 232). Actually it's our very existence which bothers us in dread. Heidegger goes on to see what the existential meaning of Nothingness is: Dasein, by reflecting upon its possibilities, becomes aware of its finitude. The awareness of death, unlike our other experience, is not concerned with the continuation of our existence. Nothingness cannot be the object of an experience but is existentially important. Even death cannot be a substitute for Nothingness, because it's feared. Nothingness is to be aware of being able not to be. Heidegger writes, "Nothingness is the Not of beings, and is hence to be as experienced from beings" (Heidegger, 2001). In explicating this sentence, Gelven comments:

Nothingness - that is, the awareness of being-able-not-to-be (...) - is the "Not" of beings; (...) It is through the rejection or the transcendence beyond mere entities that both Being and not-being can be existentially significant (Gelven, 1989, p. 117).

Darl's comments on being aware of his and others' Beings can be remembered, and the role of dread can be seen; he is no longer in the they-mode and daily concerns do not matter to him. In the following except Darl is individualized by dread:

I don't know what I am. I don't know if I am or not. Jewel knows he is, because he does not know that he does not know whether he is or not. He cannot empty himself for sleep because he is not what he is and he is what he is not. Beyond the unlamped wall I can hear the rain shaping the wagon that is ours, the load that is no longer theirs that felled and sawed it nor yet theirs that bought it and which is not ours either, lie on our wagon though it does, since only the wind and the rain shape it only to Jewel and me, that are not asleep. And since sleep is is-not and rain and wind are was, it is not. Yet the wagon is, because when the wagon is was, Addie Bundren will not be. And Jewel is, so Addie Bundren must be. And then I must be, or I could not empty myself for sleep in a strange room. And so if I am not emptied yet, I am is. (Faulkner, 1957, p. 106)

Dread is an existential through which we become aware of Nothingness. It is a state-of-mind (says what and where you are). It reminds Dasein of its thrownness. But is this thrownness concerned with Being-in-the-world? The world, in dread, is alien to Dasein. Dread focuses on Daseins as individuals, hence individualizes people. The awareness of individuality reveals one's "possibilities". Dread puts before Darl, himself, naked:

Darl has gone to Jackson. They put him on the train, laughing, down the long car laughing, the heads turning like the heads of owls when he passed. "What are you laughing at?" I said.

"Yes yes yes yes yes." (Faulkner, 1957, p. 322)

Daseins have possibilities as Darl had: either to be genuinely themselves or to lose themselves again in the "they". Darl decides to set fire to the barn (Faulkner, 1957, p. 295) and be that he himself chooses and not to be in they-mode. Dread is the uncanny awareness of the self as free to be authentic or inauthentic. Through dread consciousness becomes aware of itself as consciousness. It isolates Dasein from its environment and gives it choices on how to be. Darl, individualized, talks to himself:

"Is it the pistols you're laughing at?" I said. "Why do you laugh?" I said. "Is it because you hate the sound of laughing?"

They pulled two seats together so Darl could sit by the window to laugh. One of them sat beside him, the other sat on the seat facing him, riding backward. One of them had to ride backward because the state's money has a face to each backside and a backside to each face, and they are riding on the state's money which is incest. A nickel has a woman on one side and a buffalo on the other; two faces and no back. I dont know what that is. Darl had a little spy-glass he got in France at the war. In it it had a woman and a pig with two backs and no face. I know what that is. "Is that why you are laughing, Darl?"

"Yes yes yes yes yes yes." (Faulkner, 1957, p. 323) 


\subsubsection{Sorge}

We saw that Heidegger needs the as-structure to find meaning. Therefore we should have an existential which focuses on Dasein as Dasein to find the meaning for Dasein. This single unifying existential is called Care (Sorge) (Heidegger, 2001, p. 237). Gelven says that "if there were no unitary existential, there could be no basis for going beyond the simple enumeration of existentials, and there would then be no more possible link between the mere analysis of everydayness and the ontological ground that lies at its foundation" (Gelven, 1989, p. 112). Examining the phenomenon of dread phenomenologically steers us to the primordial existential, named care. Heidegger uses the term to describe "that aspect of Dasein's existence that concerns the way in which its own being is an issue for it" and is thus tied tightly to Dasein's "mine-ness" or "own-ness" (Malpas, 2003, p. 154). Care is Dasein's Being. Whatever Dasein does is a kind of caring. In the moments of increased caring (such as love, guilt, etc.), Dasein's individuality is amplified. Dasein is forced to stand back and reflect upon itself. The world is alienated. Dread individualizes Dasein.

The main characteristic of understanding was to project possibilities. Through the awareness of its own possibilities, Dasein projects before itself the choices of authenticity and inauthenticity. Heidegger calls this structure, in which what it means to be is an issue for Dasein, Being-ahead-of-itself. This Being-ahead does not signify the future of Dasein, but its existing qualities that make its future significant. Being-ahead-of-itself is not a random and arbitrary freedom. The world has limitations. Darl had to set fire to the barn surreptitiously. Darl as a Dasein doesn't forget his actuality. Heidegger defines Dasein as Dasein as, "Ahead of itself Being already in the world as Being alongside entities encountered within the world" (Heidegger, 2001, p. 237). That's care. Care is divided into "caring about" (Besorgen; concern) and "caring for" (Fursorge; solicitude). Darl as Dasein cares about things such as the water bucket, but cares for other Daseins, like his mother. What it means for Dasein to be is to care.

\subsection{Authenticity and Inauthenticity}

To begin this part, we would like to define authenticity as Carman does in his article as "being true to oneself" and "to be honest with oneself" and being "inwardly sincere" (Carman, 2006, p. 229). What is authentic, i. e. eigentlich, is "what is most Dasein's own" (Carman, 2005, p. 285). This inner sincerity does not refer to any transcendental moral authority such as God, and Carman (2006) says that "its intrinsic moral value is not obvious," and it is noted that this sincerity is not just telling the truth about oneself, but "to present oneself sincerely", and this self-presentation "must appear spontaneous and natural;" then he confesses that "authenticity, in any event, seems to lack the performative ambiguity bound up with the idea of sincerity, inner or outer" (p. 230). Authentic self is the basis from which freedom and choosing occur. Freedom is the determining factor in authentic existence. It has two main characteristics: it "places a terrible burden on the free man, often forcing him to seek almost any means to avoid its full significance," and it "isolates the free man from the comfort and security of an ordered existence" (Gelven, 1989, p. 157). Cash confirms Heidegger but chooses the they-mode way of Being:

It's like it aint so much what a fellow does, but it's the way the majority of folks is looking at him when he does it (Faulkner, 1957, p. 296).

For the inauthentic self, choices are already chosen, and in this case the majority of people do it. It is noteworthy to remind the readers of Sartre's "bad faith" which is his "thesis about the unwillingness of human beings to acknowledge their being radically free in this sense" (Olafson, 2006, p. 269) Freedom is the ultimate locus of authenticity. The source of authenticity lies in the range of that which is already (if vaguely) understood. Dasein has a basic understanding-ofBeing (Sein-severstandis, to understand what it means to be), but this understanding is not thematic and should be made thematic through interpretation. The way we can focus on Darl's authentic self is its voice of conscience:

"Why do you laugh?" I said. "Is it because you hate the sound of laughing?" (Faulkner, 1957, p. 323)

There's something authentic about the awareness of a guilty self. The self becomes aware of itself as responsible. A decision should be made. Dasein can choose to deny the freedom of choice and say that it is guilty because something made it do something wrong; it was not its own action, but that wrong action is forced upon Dasein. So Dasein denies its guilt to itself, as Cash does in exonerating himself:

It wasn't nothing else to do. It was either send him to Jackson, or have Gillespie sue us, because he knowed some way that Darl set fire to it. I dont know how he knowed, but he did. Vardaman seen him do it, but he swore he never told nobody but Dewey Dell and that she told him not to tell nobody. But Gillespie knowed it. But he would a suspicioned it sooner or later. He could have done it that night just watching the way Darl acted (Faulkner, 1957, p. 295).

Therefore, in this case, Dasein avoids becoming aware of its self (inauthenticity). But Dasein has another choice. It can accept its guilt and consider itself deserving the consequences of its guilt, as Darl does:

Darl has gone to Jackson. They put him on the train, laughing, down the long car laughing, the heads turning like the heads of owls when he passed. "What are you laughing at?" I said.

"Yes yes yes yes yes." (Faulkner, 1957, p. 322)

Darl, from the beginning of the novel is existentially free and faces the consequences of this freedom only later in the story. In a lecture delivered at the University of Virginia in 1957, Faulkner relates, "Darl was mad from the first. He got progressively madder because he didn't have the capacity-not so much of sanity but of inertness to resist all the catastrophes that happened to the family" (Fargnoli, Golay, \& Hamblin, 2008, p. 51). In another place he calls the novel a "tour de force" (Anderson, 2007, p. 45) which itself indicates the inevitability of the world. 
Darl as a Dasein accepts that he is responsible. In this case Dasein's existence is authentic. An authentic Dasein is always willing to hear the voice of conscience. An inauthentic self lacks the awareness of what it means to be. Guilt, as an existential, is prior to morals. Morals do not determine guilt, but guilt determines the morals. Dasein first feels a call to be good and authentic, and then finds a way to satisfy that desire and hence a moral code is established. Conscience is a call. The self calls the self to call about the self and call the self to the self itself. The calling self is in dread and is unheimlich (not-at-home, uncanny); This self is distanced from the they-self. This self calls the self which is lost in the they-self. The call is to make the self abandon the company of the they-self (Gelven, 1989, p. 163). The calling is about the self in the sense that conscience awakens an awareness of the mode of existence in which the self finds itself authentic or inauthentic. The call is to the self to ask it to be authentic or inauthentic. Cash calls his own self (Faulkner, 1957, p. 296) but tries to justify himself and so is made inauthentic. But Darl has chosen his way which proves to be authentic. Heidegger admits that to be guilty is a negative form of existence and this guilt contains a Not. This Not is the "Not" of Dasein's finitude. Hence to be guilty is the basis of a "notness" (Nichtigkeit; nullity) for Dasein. This notness means as all of Dasein's possibilities are what can be, so too are they what cannot be (to be [honest] is a possibility like not to be [honest].) Dasein is able to exclude possibilities or accept them. So Dasein is always guilty. It means that as long as Dasein is, it is in such a way as to be the ground for not being in such a way. Thus we see that self calls the they-self to be authentic or not to be authentic; "the latter possibility is grounded in Dasein's being the basis of a notness - guilt" (Gelven, 1989, p. 165).

Now let's turn to existentiality. What is projected in conscience? Being guilty. Among Dasein's possible ways of existence is to be guilty. Dasein is the ground for its notness. Dasein is responsible for what Dasein is. Darl is responsible for what he himself is and finally faces the music. Guilt is Dasein's ownmost. As was mentioned, the stateof-mind that discloses conscience is dread. The form of discourse that discloses conscience is keeping silent (reticence). We must hear the call. The inauthentic mode of discourse is loudness. Although most of the events are narrated by Darl, it should be remarked that he is one of the most reticent characters in the story and most of his monologues are streams of consciousness. Heidegger calls the disclosure of conscience Entschlossenheit (very similar to Erschlossenheit, disclosedness) or what Macquarrie and Robinson have translated as resoluteness (Heidegger, 2001, p. 314). To be authentic Dasein must be resolute, free to choose its way of existence. Authenticity is resisting conformism. Cash is not authentic in this sense. He cannot be himself and cannot help being a conformist (in the following excerpt, the phrase "in a clean way" suggests more focus on conformism and the they-mode):

But I thought more than once before we crossed the river and after, how it would be God's blessing if He did take her outen our hands and get shut of her in some clean way (Faulkner, 1957, p. 296).

And he finally comes to the conclusion that:

And I reckon they aint nothing else to do with him but what the most folks say is right (Faulkner, 1957, p. 296).

And it is not irrelevant to quote Carman (2006) talking about Heidegger's authenticity that:

Even the most authentic existence therefore presupposes some normative social background or other, whereas what characterizes the undifferentiated and inauthentic modes is their routine and desensitized conformity to the average understanding that happens to prevail in society (p. 234).

"Authenticity is coming into one's own," (ibid) and is consisted of two elements, "resoluteness" and "forerunning". To be resolute is to "remain sensitive to the unique demands of the concrete 'situation' (Situation), as opposed to subsuming it under generic rules and categories of thought, thus reducing it to a mere 'general state of affairs' (allgemeine Lage) and responding with rigid, preconceived attitudes and behaviors" (ibid). Note that the authentic self is in the world and with the others. Dasein alone is responsible for the way it exists and Cash confirms that only Darl was responsible for what he did, "It wasn't nothing else to do. It was either send him to Jackson, or have Gillespie sue us" (Faulkner, 1957, p. 295). Conscience and guilt are grounds for the authentic manner of existence. A resolute Dasein is guilty and is aware of it and wants to have a conscience. The nature of this realization and awareness makes Dasein resolute. Guilt and conscience "focus, then, upon authentic existence, which has been phenomenologically interpreted as 'anticipatory resoluteness"” (Gelven, 1989, p. 167).

\section{Conclusion}

Darl is the character narrating most of the story. Faulkner makes him a cruel and at the same time good character, though he may be an unreliable narrator. He torments Jewel and Dewey Dell and has an unstable personality, but Faulkner entrusts in him the only description of Addie's death in the novel. Darl dreams and records his various musings and 'that the material world trumps the imaginative one in this way suggests Faulkner's abiding interest in the fate of the artist in the world" (Towner, 2008, p. 26). This paper approached the authenticity of Darl, under the shadow of Seinsfrage, ontologically, as it was Heidegger's most important question in philosophy. Darl was studied as a Dasein whose Being mattered to him. Only then a range of existentials has been investigated, in the order of the most general one, Being-in-the-World, to the most specific, Sorge. It has also been said that the authentic self is the basis from which freedom and choosing occur. Freedom was the determining factor in the authentic existence and placed "a terrible burden on the free man" and isolated "the free man from the comfort and security of an ordered existence" (Gelven, 1989, p. 157). This same occurred to Darl and he lost his position in society because of his nonconformist ideas and actions. This nonconformity was the result of his freedom and resulted in the responsibility followed. His authentic life was the final conclusion. 


\section{References}

Anderson, J. D. (2007). Student Companion to William Faulkner. Greenwood Publishing.

Calhoun, R. J. (1963). Existentialism, Phenomenology, and Literary Theory. South Atlantic Bulletin, 4-8.

Carman, T. (2005). Authenticity. In H. L. Dreyfus, \& M. A. Wrathall, A Companion to Heidegger (pp. 285-296). Blackwell Publishing.

Carman, T. (2006). The Concept of Authenticity. In H. L. Dreyfus, \& M. A. Wrathall, A Companion to Phenomenology and Existentialism (pp. 229-239). Blackwell Publishing.

Cooper, D. E. (1999). Existentialism, A Reconstruction. Blackwell Publishing.

Crowell, S. (2006). Husserlian Phenomenology. In H. L. Dreyfus, \& M. A. Wrathall, A Companion to Phenomenology and Existentialism (pp. 9-30). Blackwell Publishing.

Dreyfus, H. L. (1995). Being-in-the-World: A Commentary on Heidegger's Being and Time, Division I. The MIT Press.

Dreyfus, H. L., \& Wrathall, M. A. (2006). The Roots of Existentialism. In H. L. Dreyfus, A Companion to Phenomenology and Existentialism (pp. 137-161). Blackwell Publishing.

Fargnoli, N. A., Golay, M., \& Hamblin, R. W. (2008). Critical Companion to William Faulkner: A Literary Reference to His Life and Work. New York: Facts on File.

Faulkner, W. (1957). As I Lay Dying. Vintage International.

Gelven, M. (1989). A Commentary on Heidegger's Being and Time. Northern Illinois University Press.

Head, D. (2006). The Cambridge Guide to Literature in English. Cambridge University Press.

Heidegger, M. (2001). Being and Time. (J. Macquarrie, \& E. Robinson, Trans.) Blackwell Publishing.

Inwood, M. (1997). Heidegger: A Very Short Introduction. New York: Oxford University Press.

Inwood, M. (1999). A Heidegger Dictionary. Oxford: Blakwell Publishing.

Kaufman, W. (1975). Existentialism from Dostoevsky to Sartre. New York: Penguin Publishing.

Malpas, J. (2003). Martin Heidegger. In R. C. Solomon, \& D. Sherman, The Blackwell Guide to the Continental Philosophy (pp. 143-162). Blackwell Publishing.

Mulhall, S. (2005). Heidegger and Being and Time. New York: Routledge Press.

Olafson, F. A. (2006). Freedom and Responsibility. In H. L. Dreyfus, \& M. A. Wrathall, A Companion to Phenomenology and Existentialism (pp. 263-270). Blackwell Publishing.

Sheehan, T. (2005). Dasein. In H. L. Dreyfus, \& M. A. Wrathall, A Companion to Heidegger (pp. 193-213). Blackwell Publishing.

Towner, T. M. (2008). The Cambridge Introduction to William Faulkner. Cambridge University Press.

Wheeler, M. (2013, March 21). Martin Heidegger. Retrieved 2013, from The Stanford Encyclopedia of Philosophy: http://plato.stanford.edu/archives/spr2013/entries/heidegger

Wrathall, M. A., \& Dreyfus, H. L. (2006). A Brief Introduction to Phenomenology and Existentialism. In H. L. Dreyfus, \& M. A. Wrathall, A Companion to Phenomenology and Existentialism (pp. 1-6). Blackwell Publishing.

\section{Notes}

\footnotetext{
${ }^{\mathrm{i}}$ Being (capital B), das Sein, indicates the inquiries into what it means to exist, but being (small b), das Seiende, indicates the entities.

${ }^{\text {ii }}$ Heidegger rejects all of the above-mentioned characteristics attributed to Being in his first introduction to Being and Time.

iii Die frage nach den sinn von Sein.

iv Heidegger insists on readiness-at-hand because Dasein cannot understand the meaning of things independently of its existential awareness. Heidegger denies the possibility of 'objective meaning', therefore, 'meaning and interpretation take their significance in readiness-at-hand' (Gelven, 1989, p. 101).

v It means, for example, to see a pen not as (hermeneutical 'as') an object to write with, but as (apophantical 'as') an object in the world with certain characteristics.

vi The German word for 'uncanny' is unheimlich which means 'not-at-home. In English it means very strange and difficult to explain. Dread is uncanny. When Dasein is not at home, it reflects on its own Being, not that of the 'they'.
} 